J. Asiat. Soc. Bangladesh, Sci. 47(1): 79-89, June 2021 DOI: https://doi.org/10.3329/jasbs.v47i1.54188

\title{
SCREENING OF FUNGICIDES AND PLANT EXTRACTS FOR CONTROLLING BLIGHT DISEASE OF TAGETES SPP.
}

\author{
MAHFUZA AKHTER AND SHAMIM SHAMSI* \\ Department of Botany, University of Dhaka, Dhaka-1000, Bangladesh
}

\begin{abstract}
A field experiment was conducted in the Botanical research garden, Department of Botany, University of Dhaka during 2015, 2016 and 2017 to evaluate the efficacy of two fungicides and two plant extracts against blight disease of Tagetes erecta L. and T. patula L. Both the fungicides Bavistin $50 \mathrm{WP}$ and Tilt $250 \mathrm{EC}$ and leaf extracts of Azadirachta indica A. Juss. and Citrus medica L. showed effective management of the disease over the untreated check. However, among the treatments, Bavistin $50 \mathrm{WP}$ and Tilt $250 \mathrm{EC}$ at $100 \mathrm{ppm}$ concentration and A. indica and C. medica L. at $10 \%$ concentration were found significantly superior in controlling percent disease index and increasing number of healthy flowers. The number of healthy flowers was highest per plant, 17.13 in T. erecta in 2017 and 25.00 in T. patula in the year 2016.
\end{abstract}

Key words: Screening, Fungicides, Plant extracts, Blight, Tagetes spp.

\section{Introduction}

Tagetes erecta and Tagetes patula belong to Asteraceae (Compositae) family, and it is native to North and South America, but some species now become naturalized worldwide. Tagetes erecta are sometimes known as American or African marigolds, and Tagetes patulas is French marigold. French Marigolds are commonly planted in butterfly gardens as a nectar source. The florets of Tagetes spp. are rich in orange, yellow carotenoid, lutein and are used as a food color. The essential oil of the flower contains antioxidants (Politi et al. 2016). Seeds of T. erecta is a natural pesticide. Leaves are used as blood clotting agents in Ayurbedhic treatment. Plants has antifungal properties also. The plant is also used against fever, dysenteries, indigestions, ulcers, and eczemas (Ahmed et al. 2008, Ghani 2003 and Yusuf et al. 2009). It is most effective against the nematode species Pratylenchus penetrans (Olabiyi and Oyedunmade 2000 and Politi et al. 2012). The plant also has mosquitocidal potentiality (Rajasekaran et al. 2004). In Bangladesh, flowers are very popular for decorative purposes. Marigold is now a profitable cultivated crop to the farmers, but socioeconomic data and information of this

*Corresponding author: e-mail prof.shamsi@gmail.com, A part of Ph. D. thesis of first author (MA). 
flower is very scarce in Bangladesh. Diseases were major problems for marigold cultivation. Fungal or bacterial to the diseases are the main obstacles to the rapid expansion of commercial marigold cultivation in Bangladesh. In many cases, disease occurrence is an important threat for commercial cultivation of marigold, blight and leaf spot are two common diseases of Tagetes spp. Mukerji and Bhasin (1986) reported blight inflorescence leaf spot, gray mould, powdery mildew, flower and bud rot diseases of Tagetes spp. from India. Powdery mildew, gray mold, white mold (Bakr et al. 2010, Sultana and Shamsi 2011 and Rahman et al. 2015), and blight disease of marigold have been reported from Bangladesh (Aktar and Shamsi 2014, 2015, 2016, 2018a).

However, reports on the management of blight disease of Tagetes spp. are inadequate in Bangladesh (Rahman et al. 2015). Therefore, the present study was undertaken to evaluate the efficacy of selected fungicides and plant extracts against blight disease of $T$. erecta and $T$. patula. Though, as control measures, chemical fungicides and leaf extracts are reported to control blight diseases of various plant spp (Yasmin and Shamsi 2019). So, it is necessary to find out the effective and sustainable control measure of blight disease of Tagetes spp. in our country.

\section{Materials and Methods}

The field experiments were conducted in the field plots of Botanical research Garden, Dhaka University, during 2015, 2016, and 2017. Efficacy of selected fungicides and plant extract were studied on T. erecta and T. patula. The pathogenic potentiality of Alternaria alternata, the causal agent of blight symptom, was determined by the methods of Aktar and Shamsi (2014). The concentration of fungicides and plant extract was prepared following Aktar and Shamsi (2018b). Particulars of the fungicides and plant extracts are presented in Tables 1 and 2. The experimental design was followed by Islam et al. (2015-16).

The field plots were prepared in November of each experimental year. Biofertilizer was used during field preparation. Three weeks old, fifteen seedlings were transplanted in each sub-plot measuring $1.5 \times 1 \mathrm{~m}$. Spacing between sub-plots was $1 \mathrm{~m}$. The plants were spaced $25 \mathrm{~cm}$ by $25 \mathrm{~cm}$. Ten plants were randomly selected to record disease severity and production of healthy flowers.

The experimental design was random block design (RBD), having three replications. Data were recorded after 15 days of each spray. Final data were recorded after 15 days of the last spray. The percent disease index (PDI) was calculated by the formula of Rahman 
and Rashid (2008). The disease severity was recorded by using 0-9 scale. For visual estimation of severity, a 0-9 point DS scale was used for rating of all foliar diseases studied (PDI=McKinney's Index, Ghos et al. 2009).

No infection $=0,0-10 \%$ leaf area infected $=1,10-20 \%$ leaf area infected $=2,20-30 \%$ leaf area infected $=3,30-40 \%$ leaf area infected $=4,40-50 \%$ leaf area infected $=5$, $50-60 \%$ leaf area infected $=6,60-70 \%$ leaf area infected $=7,70-80 \%$ leaf area infected $=$ $8,80-90 \%$ or more leaf area infected $=9$.

The incidence and severity of blight of $T$. erecta and $T$. patula were recorded from the plants grown in gardens of Curzon Hall Campus, Dhaka University. Each plot was visited and data were recorded twice a month. Data were expressed in percentage. Similarly percent disease incidence (PDI) was recorded using the following formula:

Disease incidence $(\%)=\frac{\text { Total no. of infected plants }}{\text { Total no. of plants }} \times 100$

Two fungicides, Bavistin $50 \mathrm{WP}$ and Tilt $250 \mathrm{EC}$ at $100 \mathrm{ppm}$ concentration and leaf extracts of A. indica and C. medica at 10\% concentration, were applied on T. erecta and T. patula (Tables 1 and 2). Control plants were treated with water. A total of four sprays were done at 15 days intervals.

Table 1. Particulars of the fungicides used in the experiment.

\begin{tabular}{llcccl}
\hline $\begin{array}{l}\text { Sl. } \\
\text { No. }\end{array}$ & $\begin{array}{l}\text { Trade } \\
\text { name }\end{array}$ & Formulation & $\begin{array}{c}\text { Recommended } \\
\text { dose }(\mathrm{ppm})\end{array}$ & $\begin{array}{c}\text { Ten times lesser } \\
\text { of recommended } \\
\text { dose }(\mathrm{ppm})\end{array}$ & Manufacturers \\
\hline 1. & Bavistin & $50 \mathrm{WP}$ & 500 & 100 & BASF Bangladesh Ltd. \\
2. & Tilt & $250 \mathrm{EC}$. & 1000 & 50 & Syngenta (BD) Ltd. \\
\hline
\end{tabular}

Table 2. Particulars of the plant extracts used in the experiment.

\begin{tabular}{llll}
\hline S1. No. & Plant species & Used part & Family \\
\hline 1. & Azadirachta indica A. Juss & leaves & Meliaceae \\
2. & Citrus medica L. & leaves & Rutaceae \\
\hline
\end{tabular}

Analysis of data: Data on different parameters were analyzed following computer package MSTAT-C and means were compared using DMRT. The data were collected and evaluated by analysis of variance (ANOVA) by using STAR statistical program. 


\section{Results and Discussion}

In 2015-2017, out of four treatments, Tilt 250 EC showed promising results in controlling blight of T. erecta. Percent disease (PDI) value was lowest 3.27 in 2015, 3.27 in 2016 and 3.41 in 2017. The number of infected flowers/plant was lowest 1.57 in 2015, 2.93 in 2016, and 5.50 in 2017, respectively. The number of healthy flowers/plant was a maximum 10.13 in 2015, 14.93 in 2016, and 17.13 in 2017 (Table 3)

Bavistin 50 WP showed 6.08 in 2015, 5.65 in 2016, and 6.04 in 2017 PDI in blight infected plants. Infected flowers per plant were 4.13 in 2015, 4.53 in 2016, and 7.23 in 2017. Healthy flowers per plant were 9.17 in 2015, 9.40 in 2016, and 10.10 in 2017 (Table 3).

Table 3. Screening of fungicides and leaf extracts for controlling blight disease of T. erecta.

\begin{tabular}{llccc}
\hline $\begin{array}{l}\text { Experiment } \\
\text { year }\end{array}$ & Treatment & PDI & $\begin{array}{c}\text { No. of infected } \\
\text { flower/plant }\end{array}$ & $\begin{array}{c}\text { No. healthy } \\
\text { flower per plant }\end{array}$ \\
\hline 2015 & Bavistin 50 WP & $6.08^{\mathrm{b}} \mathrm{b}^{\mathrm{a}}$ & $4.13^{\mathrm{ab}}$ & $9.17^{\mathrm{ab}}$ \\
& Tilt 250 EC & $3.27^{\mathrm{d}}$ & $1.57^{\mathrm{d}}$ & $10.13^{\mathrm{a}}$ \\
& Azadirachta indica & $4.76^{\mathrm{c}}$ & $3.17^{\mathrm{c}}$ & $8.40^{\mathrm{b}}$ \\
& Citrus medica & $6.04^{\mathrm{b}}$ & $3.30^{\mathrm{bc}}$ & $6.30^{\mathrm{c}}$ \\
& Control & $7.54^{\mathrm{a}}$ & $4.53^{\mathrm{a}}$ & $5.23^{\mathrm{c}}$ \\
& CV (\%) & 10.18 & 13.27 & 8.96 \\
& Bavistin 50 WP & $5.65^{\mathrm{ab}}$ & $4.53^{\mathrm{ab}}$ & $9.40^{\mathrm{d}}$ \\
& Tilt 250 EC & $3.27^{\mathrm{d}}$ & $2.93^{\mathrm{c}}$ & $14.93^{\mathrm{a}}$ \\
& Azadirachta indica & $4.77^{\mathrm{c}}$ & $3.33^{\mathrm{c}}$ & $12.67^{\mathrm{b}}$ \\
& Citrus medica & $5.03^{\mathrm{bc}}$ & $4.07^{\mathrm{b}}$ & $11.07^{\mathrm{c}}$ \\
& Control & $6.37^{\mathrm{a}}$ & $4.83^{\mathrm{a}}$ & $7.80^{\mathrm{e}}$ \\
& CV (\%) & 7.58 & 7.30 & 4.72 \\
& Bavistin 50 WP & $6.04^{\mathrm{a}}$ & $7.23^{\mathrm{ab}}$ & $10.10^{\mathrm{c}}$ \\
& Tilt2 50 EC & $3.41^{\mathrm{d}}$ & $5.50^{\mathrm{d}}$ & $17.13^{\mathrm{a}}$ \\
& Azadirachta indica & $4.58^{\mathrm{c}}$ & $6.57^{\mathrm{bc}}$ & $16.53^{\mathrm{a}}$ \\
& Citrus medica & $5.18^{\mathrm{b}}$ & $6.13^{\mathrm{cd}}$ & $13.67^{\mathrm{b}}$ \\
& Control & $6.27^{\mathrm{a}}$ & $7.83^{\mathrm{a}}$ & $8.60^{\mathrm{d}}$ \\
& CV (\%) & $3.17^{\mathrm{a}}$ & 8.06 & 5.89 \\
\hline
\end{tabular}

*Means followed by the same letter within a column did not differ significantly at the $5 \%$ level by DMRT. 
Leaf extract of Azadirachta indica showed 4.76 in 2015, 4.77 in 2016, and 4.58 in 2017 PDI in blight infected plants. Infected flowers per plant were 3.17 in 2015, 3.33 in 2016 and 6.57 in 2017. Healthy flowers per plant were 8.40 in 2015, 12.67 in 2016, and 16.53 in 2017 (Table 3).

Citrus medica showed 6.04 in 2015, 5.03 in 2016 and 5.18 in 2017 PDI in blight infected plants. Infected flowers per plant were 3.30 in 2015, 4.03 in 2016, and 6.13 in 2017. Healthy flowers per plant were 6.30 in 2015, 11.07 in 2016, and 13.67 in 2017 (Table 3).

Whereas the control plant showed 7.54 in 2015, 6.37 in 2016, and 6.27 in 2017 PDI in blight infected plants. Infected flowers per plant were 4.53 in 2015, 4.83 in 2016, and 7.83 in 2017. Healthy flowers per plant were 5.23 in 2015, 7.80 in 2016, and 8.60 in 2017 (Table 3 and Plate 1, A-E).

In 2015-2017, out of four treatments, Tilt showed the promising result in controlling blight of T. patula, Percent disease index (PDI) value was lowest at 2.91 in 2015, 4.27 in 2016, and 3.23 in 2017, respectively. The number of infected flowers/plant was lowest at 3.30 in $2015,1.70$ in 2016, and 2.80 in 2017, respectively. The number of healthy flowers/plant, was maximum 15.30 in $2015,25.00$ in 2016, and 23.17 in 2017, respectively. Whereas Bavistin showed 5.28 in 2015, 5.31 in 2016, and 5.29 in 2017, respectively PDI in blight infected plants (Table 4).

Infected flowers per plant were 4.40 in 2015, 3.67 in 2016, and 3.63 in 2017, respectively. Healthy flowers per plant were 12.97 in $2015,11.07$ in 2016, and 15.73 in 2017, respectively (Table 4).

In 2015, plants treated with leaf extracts of $A$ indica showed 3.48 PDI, number of infected flowers per plant 4.10, and number of healthy flower per plant 15.17 respectively. In 2016, plants treated with extracts of A. indica showed PDI 4.96, number of infected flowers per plant 6.33, and number of healthy flower per plant 23.47, respectively. Moreover, in the 2017 experimental year, PDI 4.36, the number of infected flowers per plant 2.90 , and the number of healthy flower per plant 21.43 were recorded (Table 4).

Whereas, in the experimental year 2015, plants treated with showed leaf extract of $C$. medica showed PDI 4.45, the number of infected flowers per plant 4.57, and the number of healthy flower per plant 12.17, respectively. In the 2017 experimental year, PDI 5.03, the number of infected flowers per plant 3.30, and the number of healthy flowers per plant 15.53 were recorded (Table 4). 

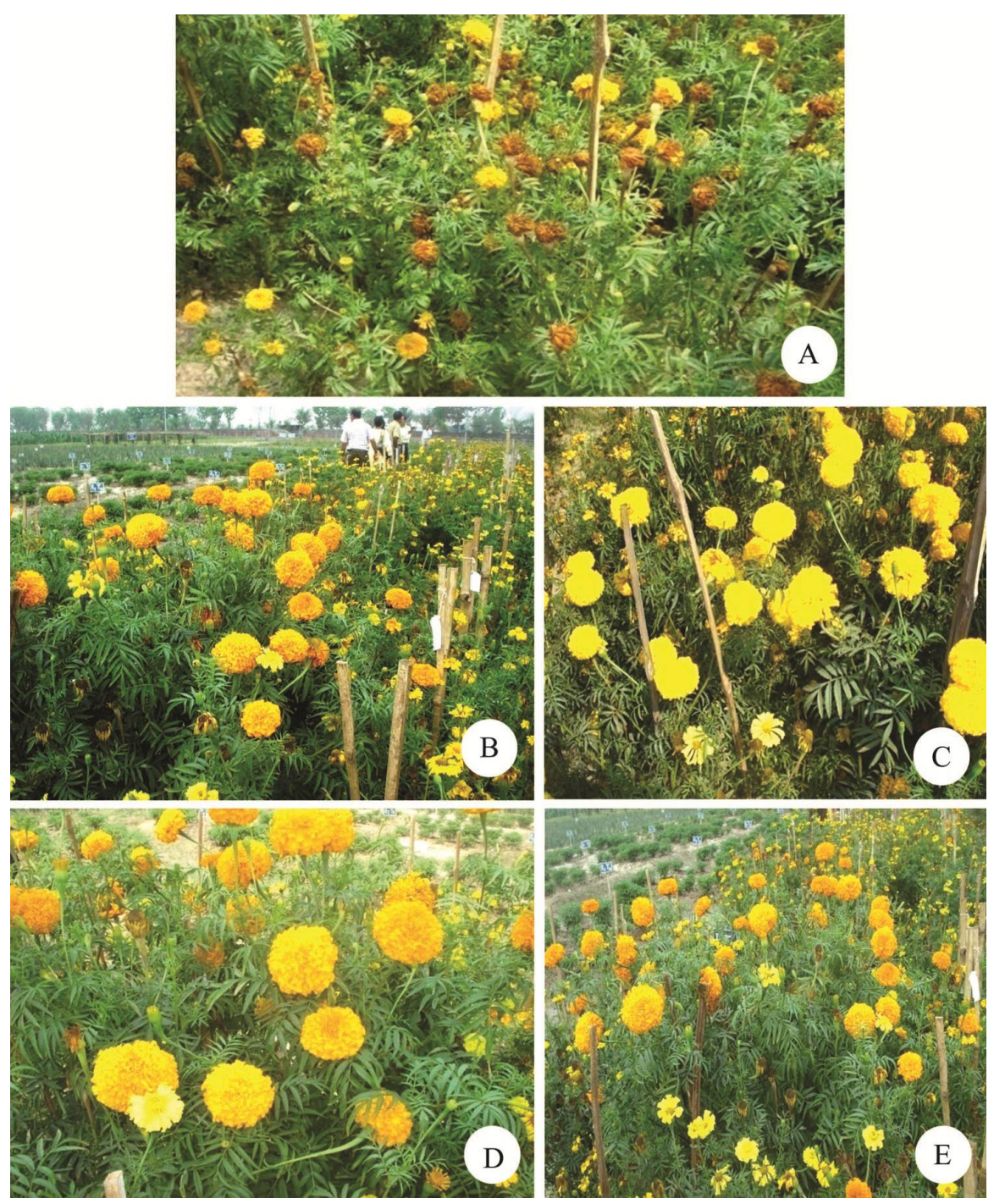

Plate 1. Effects of fungicides and leaf extracts on the yield of flowering of T. erecta: A. Control, B. Bavistin, C. Tilt, D. A. indica and E. C.medica.

Subsequently, Control plants treated with water showed 5.44 in 2015, 6.20 in 2016, and 5.80 in 2017 PDI in blight infected plants. Infected flowers per plant were 6.17 in 2015, 6.80 in 2016, and 4.63 in 2017. Healthy flowers per plant were 9.53 in $2015,8.33$ in 2016, and 7.77 in 2017 (Table 4 and Plate 2, A.E). 
Table 4. Screening of fungicides and leaf extracts for controlling light disease of T.patula.

\begin{tabular}{llccc}
\hline $\begin{array}{l}\text { Experiment } \\
\text { year }\end{array}$ & Treatment & PDI & $\begin{array}{c}\text { No. of infected } \\
\text { flower/plant }\end{array}$ & $\begin{array}{c}\text { No. healthy } \\
\text { flower per plant }\end{array}$ \\
\hline 2015 & Bavistin 50 WP & $5.28^{\mathrm{a}^{*}}$ & $4.40^{\mathrm{b}}$ & $12.97^{\mathrm{b}}$ \\
& Tilt 250 EC & $2.91^{\mathrm{d}}$ & $3.30^{\mathrm{c}}$ & $15.30^{\mathrm{a}}$ \\
& Azadirachta indica & $3.48^{\mathrm{c}}$ & $4.10^{\mathrm{b}}$ & $15.17^{\mathrm{a}}$ \\
& Citrus medica & $4.45^{\mathrm{b}}$ & $4.57^{\mathrm{b}}$ & $12.17^{\mathrm{b}}$ \\
& Control & $5.44^{\mathrm{a}}$ & $6.17^{\mathrm{a}}$ & $9.53^{\mathrm{c}}$ \\
& CV (\%) & 6.02 & 21.62 & 3.87 \\
& Bavistin 50 WP & $5.31^{\mathrm{b}}$ & $3.67^{\mathrm{b}}$ & $11.07^{\mathrm{b}}$ \\
& Tilt 250 EC & $4.27^{\mathrm{c}}$ & $1.70^{\mathrm{c}}$ & $25.00^{\mathrm{a}}$ \\
& Azadirachta indica & $4.96^{\mathrm{b}}$ & $6.33^{\mathrm{a}}$ & $23.47^{\mathrm{a}}$ \\
& Citrus medica & $5.08^{\mathrm{b}}$ & $6.50^{\mathrm{a}}$ & $20.10^{\mathrm{a}}$ \\
& Control & $6.20^{\mathrm{a}}$ & $6.80^{\mathrm{a}}$ & $8.33^{\mathrm{b}}$ \\
& CV (\%) & 6.39 & 10.67 & 20.89 \\
& Bavistin 50 WP & $5.29^{\mathrm{ab}}$ & $3.63^{\mathrm{b}}$ & $15.73^{\mathrm{b}}$ \\
& Tilt250 EC & $3.23^{\mathrm{d}}$ & $2.80^{\mathrm{c}}$ & $23.17^{\mathrm{a}}$ \\
& Azadirachta indica & $4.36^{\mathrm{c}}$ & $2.90^{\mathrm{c}}$ & $21.43^{\mathrm{a}}$ \\
& Citrus medica & $5.03^{\mathrm{b}}$ & $3.30^{\mathrm{bc}}$ & $15.53^{\mathrm{b}}$ \\
& Control & $5.80^{\mathrm{a}}$ & $4.63^{\mathrm{a}}$ & $7.77^{\mathrm{c}}$ \\
& CV (\%) & 6.68 & 10.50 & 8.46 \\
\hline
\end{tabular}

*Means followed by the same letter within a column did not differ significantly at the $5 \%$ level by DMRT.

Various workers in different countries of the world evaluated the efficacy of other fungicides against Colletotrichum spp., Phomopsis vexans, Macrophomina phaseolina, Rhizopus nodosus, Fusarium spp., Phoma spp., Botryodiplodia theobromae, Colletotrichum gloeosporioides, Sclerotium rolfsii and Alternaria spp., under laboratory and field conditions (Stirling et al. 2004,Chowdhury et al. 2015, Mamun et al. 2016 and Hosen et al. 2016). But fungicide's toxicity is not always restricted to the target pest organism, also observed in mammals, including humans (Belpoggi et al. 2002). Most fungicides can cause acute toxicity, and some cause chronic toxicity as well (Goldman 2008). The World Health Organization (WHO) and the United Nations Environment Program (UNEP) estimates that each year, three million workers in agriculture in the developing world experience severe poisoning from pesticides, about 18,000 of whom die (Panday et al. 1983). However, care should be taken during the use of the fungicides. 
Some pest management researchers have focused on developing alternative inputs to synthetic chemicals for controlling diseases (Pal and Gardener 2006 and Baker 1987). One of them is the use of biological antagonists and plant extracts. Biological control presents a better alternative with relatively low cost, no side effects, and reduced resistance development in the pathogen (Okigbo and Nmeka 2005).
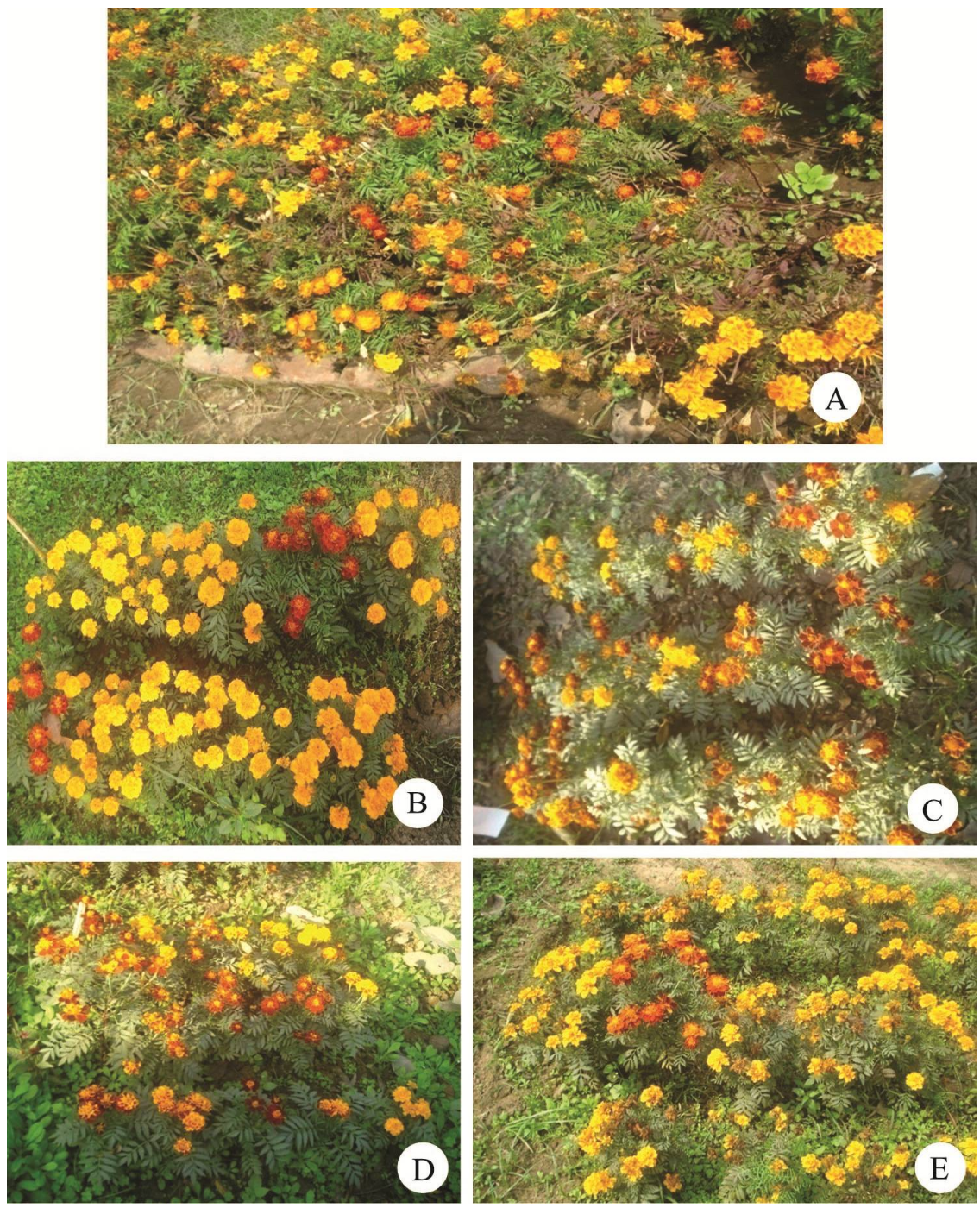

Plate 2. Effects of fungicides and leaf extracts on the yield of flowering of T. patula: A. Control, B. Bavistin, C. Tilt, D. A. indica and E. C. medica. 
Islam et al. (2015-2016) observed that in field trial Tilt 200 EC (Propiconazole, Dose 0.1 $\mathrm{ml} / \mathrm{l}$ ) and Secure $600 \mathrm{WG}$ (Mancozeb + Fenamidone, Dose $2 \mathrm{~g} / \mathrm{l}$ ) were significantly reduced the severity of Botrytis blight of marigold. Autostin and Tilt at $100 \mathrm{ppm}$ concentration and Azadiractaindica and Citrus limon at 10\% concentration were found significantly superior in controlling the disease severity, PDI (Percent disease index), and increasing number of healthy leaves.

As control measures, chemical fungicides, leaf extracts are successfully reported to control leaf spot and anthracnose diseases (Yasmin and Shamsi 2019).

The present study also reported that the fungicides Bavistin $50 \mathrm{WP}$ and Tilt $250 \mathrm{EC}$ and leaf extracts showed effectively manage the disease over control. However, among the treatments Bavistin $50 \mathrm{WP}$ and Tilt $250 \mathrm{EC}$ at $100 \mathrm{ppm}$ concentration and Azadirachta indica A. Juss. and Citrus medica L. at $10 \%$ concentration was found significantly superior in controlling PDI and increasing number of healthy flowers.

\section{Conclusion}

Blight disease drastically damaged the plants of Tagetes. Considering the importance of the plant, it is necessary to save the plaat immediately. The present investigation is the first approach to controlling the blight disease of the plants mentioned above in Bangladesh. The findings of this research work will be helpful for designing a proper management of blight disease. Application of Bavistin and Tilt at $100 \mathrm{ppm}$ concentration may be commercially used for managing blight disease of $T$. erecta and $T$. patula. For more confirmation, the above mentioned fungicides also need to 2-3 years trial in field condition. In small-scale gardening or those persons who want to maintain the plants in the yard for medicinal or recreation purposes, A. indica and C. medica at $10 \%$ concentrations can be useful for controlling blight disease.

\section{Acknowledgement}

The authors express their gratitude to the Chairman, Department of Botany, University of Dhaka, for providing necessary laboratory facilities and thanks to "Research and Higher Education Fund of the Prime Ministers' Office, Govt. of the People's Republic of Bangladesh" for their financial support in the form of scholarship during the tenure of research work. 


\section{References}

Ahmed, Z.U., Z.N.T. Begum, M.A. Hossain, M. Khodoker, S.M.H. Kabir, M. Ahmed, A.T.A. Ahmed, A.K.A. Rahman and E.U. Haque. 2008. Encyclopedia of Flora and Fauna of Bangladesh. Vol. 6. Asiatic Soc. of Bangladesh, Dhaka. pp. 408.

Aktar, M. and S. Shamsi. 2014. Report on Alternaria blight of Tagetes erecta and Tagetes patula caused by Alternaria alternata (Fr.) Keissler. J. Asiat. Soc. Bangladesh Sci. 40(1): 133-140.

Aktar, M. and S. Shamsi. 2015. Blight of two species of marigold (Tagetes) caused by Aspergillus Fumigatus Fresenius. Bangladesh J. Plant Pathol. 31(1\&2):1-6.26.

Aktar, M. and S. Shamsi. 2016. Report on blight of Tagetes spp. caused by Curvularia lunata (Wakker) Boedijn. Bangladesh J. Bot. 45(1): 167-173.

Aktar, M. and S. Shamsi. 2018a. Incidence and Severity of Blight Disease of Tagetes erecta and T. patula Bioresearch Communications. 4(1): 464-469.

Aktar, M. and S. Shamsi. 2018b. In-vitro evaluation of fungicides and plant extracts against pathogenic fungi of Tagetes spp. Bangladesh J. Plant Pathol. 34 (1\&2): 5-12.

Baker, K.F. 1987. Evolving concepts of biological control of plant pathogens. Annu. Rev. Phytopathol. 25: 67-85.

Bakr, M.A., M.S. Hossain and H.U. Ahmed. 2010. A guide to Disease identification, data recording, rating scale and grading system of major diseases of important crops. Bangladesh Agricultural Research Institute. Joydebpur, Gazipur. pp. 74.

Belpoggi, F. Soffritti, M. Guarino, M.Lambertini,L. Cevolani, D. and Maltoni. 2002. Results of long term experimental studies on the carcinogenicity of ethylenebis- dithiocarbamate (mancozeb) in rats. Annual New York Academic Science 982: 123-136.

Chowdhury, P. Bashar, M.A. and Shamsi, S. 2015. In vitro evaluation of fungicides and plant extracts against pathogenic fungi of two rice varieties. Bangladesh J. Bot. 44(2): 251-259.

Ghani, A. 2003. Medicinal plants of Bangladesh. Asiatic Society of Bangladesh. pp. 603.

Ghosh, P.P., D. Mandal, S. Laha and M.K. Dasgupta. 2009. Dynamics and severity modelin managing fungal diseases. The Journal of Pl. Ptotec. Sci. 1(1): 55-59.

Goldman, L.R. 2008. Encyclopedia of Public Health: Fungicides. Cited on 6 June 2008, available Fromhttp://www.answers.com/topic/fungicides?cat=technology

Hosen, S. Shamsi, S. and Bashar, M.A. 2016. In vitro efficacy of fungicides and plant extracts on the Growth of Colletotrichum gloeosporioide sPenz. \& Sacc and Sclerotium rolfsii Sacc. The causal organisms of anthracnose and soft rot of jute. Dhaka Univ. J. Bio. Sci. 25(2): 195-199.

Islam, M.N., M.M. Momtaz, M. Karim, K.M. Alam and A. Ayub. 2015-2016. Annual Report. Plant Pathology, BARI.Joydebpur, Gazipur. pp. 25-26

Mamun, M.A. Shamsi, S. and Bashar, M.A. 2016. In vitro evaluation of fungicides and plantextracts against pathogenic fungi of jute seeds. Biores. Comm. 2(1): 189-192.

Mukerji, K.G. and J. Bhasin. 1986. Plant diseases of India. A source Book. Tatta Mc.Grew-Hill Publishing Company Ltd. New Delhi. pp. 467.

Okigbo, R.N. and Nmeka, I.A. 2005. Control of yam tuber rot with leaf extracts of Xylopiaaethiopics and Zingiber officinals. Afri J. Biotechnol. 4(8): 804-807.

Olabiyi, T. I. and E. E. A. Oyedunmade. 2000. Marigold (Tagetes erecta L.) as interplant with cowpea for the control of nematode pests. African Crop Science Conference Proceedings 8: 1075-1078.

Panday, D.K.,H.Chandra, N.N. Tripathiand S.N. Dixit. 1983. Fungitoxicity of some higher with special reference to the synergistic activity among some fungitoxicants. Phytopathol. $Z$. 106: $226-232$. 
Pal, K.K. and B. M Gardener 2006.Biological Control of Plant Pathogens. The Plant Health Instructor. 2: 1117-1142.

Politi, F. A., C. M. Figueria, A.M. Arúio, B.R. Sampieri, M.I. Mathias, M.P. Szabó, G.H. Bachara, L.C.D. Santos, W. Vilegas and R.C. Pietro. 2012. Acaricidal activity of ethanoloi extract from aerial parts of Tagetes patula L. (Asteraceae against larvae and engorged adult females of Rhipicephalus sanguineus (Latreille, 1806). Parasit Vectors 17(5): 295.

Politi, F. A. S., N.J. Damieli, Da Silva, A.1.Moro, I. Jacob, G. Mariana Lopes, G.R.V. Carvalho, P.R. C. L.Rodrigue, G.A. F.Maysa. 2016. Insecticidal activity of an essential oil of Tagetes patula L. (Asteraceae) on common bed bug Cimex lectularius L. and molecular docking of major compounds at the catalytic site of ClAChE1". Parasitology Res. 116(1): 415-424.

Rahman, D., M. Hossain, T.K. Dey, S.R. Sarker, M. Nonaka and N. Harada. 2015. First report of white mould caused by Sclerotinia sclerotiorum on Marigold (Tagetes erecta) in Bangladesh. J. Plant Pathol. 97(2): 391-403.

Rahman, M.L. and M.H. Rashid. 2008. Rating scale and severity index of crop diseases - A review. Bangladesh Phytopathologycal Society. Plant Pathology Division, BARI, Joydebpur, Gazipur. pp. 44.

Rajasekaran, T. G., A. Ravishankar and B. Reddy. 2004. In vitro growth of Tagetes patula L. hairy roots production of thiophenes and its mosquito larvicidal activity. Indian J. Biotech. 3: 92-96.

Stirling, A.M.,G.R.Stirling, K.G. egg and A.C. Hayward . 2004. Effect of copper fungicide On Colletotrichum gloeosporioides and other microorganisms on avocado leaves and fruit. Aus. J. Agri. Res. 50(8):1459-1468.

Sultana, R. and S. Shamsi. 2011. Alternative and Collateral hosts of Botrytis cinerea causing Botrytis Grey mold of chickpea in Bangladesh. Bangladesh J. Plant Pathol. 27(1\&2): 73-74.

Yasmin, Z. and S. Shamsi. 2019. Screening of fungicides and plant extracts in controlling leaf spot and anthracnose diseases of Rauwolfia serpentina (L.) Benth. ex Kurz. Bioresearch Communications (BRC). 5(2): 700-699.

Yusuf, M., J. Begum and J.U. Chowdhury. 2009. Medicinal plants of Bangladesh. BCSIR Laboratories, Chittagong. pp. i-x.+ 794. 